\title{
Product versus Celebrity - An eye-tracking experiment for the determination of the attention-catcher in advertising
}

\author{
Puiu NISTOREANU \\ Bucharest University of Economic Studies, Romania \\ puiu.nistoreanu@com.ase.ro \\ Corina PELAU \\ Bucharest University of Economic Studies, Romania \\ corina.pelau@fabiz.ase.ro \\ Laura LAZAR \\ Bucharest University of Economic Studies, Romania \\ laura_lazar10@yahoo.com
}

PICBE |

\begin{abstract}
Celebrity endorsement has been frequently used in advertising as consumers are attracted and tend to imitate the behavior of the star. In the past years, celebrities have been a frequent mean of attracting the attention of the consumer towards an advertising. In an era with an over-load of information and ads, the glamour of the celebrities has had the power to increase the visibility of the advertised product. Besides the positive effects which celebrities bring to an increase of attention of the consumers, their endorsement can also have negative consequences. One of these undesired effects is the overshadowing of the advertised product by the celebrity. Consumers will have the tendency to watch the celebrity for a longer time and their attention is distracted from the advertised product. In an eyetracking experiment we analyze the fact that the celebrity might distract the attention of the consumer from the advertised product and its logo. The results have shown that the participants have the tendency to watch the logo of a product for a longer time in advertising without celebrities. In opposition to this, in advertising endorsing celebrities, the attention is caught by the celebrity.
\end{abstract}

Keywords: celebrity endorsement, consumer, advertising, attention, eye-tracking, neuroscience.

\section{Introduction}

Celebrity endorsement in advertising has been a common practice in the past years, but few studies have been preoccupied about their efficiency for the advertised brand. If most of the researches focus on the congruency between the celebrity, the brand and the consumer (Albert et al., 2017), only few studies have focused on the over-shadowing effect of the brand by the celebrity (Erfgen et al., 2015). Mehta (1994) shows in his study that consumers who watch an advertising, featuring a celebrity have the tendency to talk more about the celebrity's characteristics. The consumers tend to watch familiar faces for longer time than unfamiliar ones (Devue et al., 2009). In a similar way consumers will watch for a longer time the familiar faces of celebrities and they will be distracted from the more unfamiliar advertised brand, product or logo. Erfgen et al. (2015) prove in their research the overshadowing effect of the brand by their celebrity endorsers and determine the conditions in which this effect can be reduced. 


\section{Literature review}

A celebrity is a famous person who enjoys a special recognition from the public. For this reason, using famous advertisers in international advertisements is very successful as they attract consumers' attention through their name and image. The famous people are like human brands, as their activities and performances on the stage, their private life activity, their online activity, become branding and marketing exercises. The celebrity's everyday life and their choices are private, but these are performed in public. These actions create brand identities, so the companies sell different product brands through celebrity endorsement (Holmes \& Redmond, 2014).

Celebrity endorsement is also a method of money-burning. This happens because consumers pay a lot of attention to their social position. They always want to wear the right clothes, to drink the right drink, to buy the right perfume. If a person sees two different advertisements for two different products, one with a celebrity and the other one without, then he thinks that the product promoted by the celebrity is better, that it has a higher value. This fact influences his purchasing decision. The stars are like a reference group for a lot of consumers. They search information, are attracted by celebrities, invest energy and time to look like them. This happens because celebrities become symbols, valued characters for the normal people through their lifestyle and social media presence. It's about a social influence theory. So, a normal person tries to imitate a public person to look like her, in an identification process. A consumer has a similar celebrity`s behavior and purchase brands they endorse in order to shape their own image (Alberta et al, 2017).

The stars also serve as a signaling strategy for companies. They have the ability to increase the market acceptance and the sales, making in this way the advertising efficient. Add to this the fact, the celebrities bring their own experience with them, which leads to a closer and more familiar relationship between them and consumers. Very often, the consumers see the celebrity endorsers as part of their own lives and that's the reason why they feel free to react and express opinions about them. Sometimes they are motivated by the attitude, emotions or behavior of the public person (Bagozzi \& Dholakia, 2002). The fans are consumers who are interconnected, who react to the brand with enthusiasm and create value for the brand (Schau et al., 2009).

With a few characteristics like attractiveness, charisma or an exceptional lifestyle, celebrities enjoy a high recognition and are different from the normal people. According to Friedman and Friedman (1979), celebrity endorser is an individual who is known by the public achievements in areas other than that of the product class endorsed. Compared to other endorsers, the famous people always manage to touch a higher level of attention, recognition and loyalty. Nowadays, in the age of intense competition, where all companies aim to stay in the consumer's mind and encourage them to buy their products, celebrity endorsement is a real opportunity. The celebrities can be like a catalyst. "Celebrities as brands" is a sales challenge. The current concept of celebrity management is far from ideal. Now, this phenomenon is only considered as a business instrument that brings benefits to a brand. Another important fact, is the match between celebrity and brand. The testimonials have to fit together with the promoted products. The presence of celebrity in the message of an advertising should be contextual and not random.

Celebrities in advertising are a trend today. These exist, however, since the advertising exists. The potential of this type of advertising is quite high. The so-called 
testimonials are positive drivers for the image of a company. For this reason, those responsible for marketing are looking for such celebrities that are attractive, popular, trustworthy and successful. Through these properties, the emotions come into the use of a product. People today need the testimonials, because they are overwhelmed by the complexity of everyday life, so they need role models and ideals, as a survival strategy. The celebrities therefore play an important role not only for advertising but also for the daily lives of consumers. The role models, their behavior, and thus the products used by them, simplify people's orientation in life and make it easier to decide. That's why the testimonial advertising works.

Byrne et al. (2003) believe that the key to success in a standardized advertising campaign is to find a famous, credible, and internationally recognized person. Some products are not very different in price or quality. Celebrity has an important role here: to bring consumers closer to a specific brand and give them the appropriate impulse to make the desired buying decision. This happens also because a well-known person in commercials is more sympathetic and more convincing than an unknown. So one should also know the degree of sympathy and degree of confession of the testimonial before selecting it for an advertisement.

According to McCracken (1989), a famous person has a better influence on a person's buying behavior than a normal person. In addition, he still believes that the advertisements with celebrities are typical for the modern marketing. The personalities from the advertisements are capable to transfer their known image on the promoted products. This thing is beneficial for the customers. In the beginning, this trend was accepted as an opportunity by the organizations and these have transformed this type of advertising into a tool of communication. It is said that this novelty will increase the companies' market share and that in a relatively short period of time it will create an important perception of the brand among the consumers. Each year, companies spend millions of dollars on various contracts with stars. This means that celebrities today have a very important role in the advertising industry. For example, the company Pepsi has signed contracts with several celebrities, such as Puff Diddy or Cindy Crawford to promote Diet Pepsi (McCracken, 1989). These things prove that this new communication tool is very popular and that producers pay a heavy price to attract consumers through a celebrity. The match-up between celebrity and promoted brand is very important that's why celebrity endorsement and its effects remain an important aspect for marketers and managers (Bergkvist \& Zhou, 2016).

It has been proven that one celebrity is more persuasive than another endorser. The popularity of the stars offers them a higher persuasive power. Customers tend to make a more positive purchasing decision when the products are being promoted by a well-known person. But there must be a match between celebrity and product, a compatibility between these, not forced and artificial, but natural.

Celebrity endorsement is now used as a communication strategy. A well-chosen celebrity can attract consumers and their attention to a certain product or brand. For example, the singer Fergie has shown the consumer how many kilograms she has lost, certainly with the help of the company Weight Watchers (Kotler \& Keller, 2008). The choice of figure from advertising, in this case the celebrity has a capital role. The public personality selected by the company should be popular and known by the public. In addition, this must necessarily be suitable for the promoted products or services. A celebrity that is known to 
the public, but has a rather negative effect within several audiences would be the famous singer Britney Spears (Kotler \& Keller, 2008). In contrast, Oprah Winfrey, has a positive impact on the audience. So she could go on and promote a lot of products. Celebrities appear everywhere, in all sorts of messages. The personalities of the sports sector, for example, fit very well into advertisements for clothing, drinks or sports goods. One of the best celebrity brand ambassadors is the cyclist Lance Armstrong (Kotler \& Keller, 2008). After winning the battle with cancer and winning six more Tour de France competitions, he promoted several organizations that produce sports goods and bicycles, including Nike, Trek and Powerbar. His life story, his character and his courage bring him also numerous advertising contracts with other companies except the sports sector, such as Subaru or Coca-Cola (Kotler \& Keller, 2008). The celebrities, however, could act more strategically, not just to promote a particular brand, but also to help the placement and selling. An example would be Tiger Woods, the famous golfer. He has signed a deal with Nike since 1996, increasing Nike's market share from $1 \%$ to $6 \%$ (Kotler \& Keller, 2008).

According to Armstrong and Kotler, marketers usually sign contracts with various personalities, actors, athletes, or musicians to promote and provide information about certain products and services. The selected celebrities should be chosen very well, so that they fit with the promoted products, so that the advertising ultimately brings the company a profit (Kotler \& Armstrong, 2011, p. 420). But it is a gain not only on the part of companies, but also for public figures. Very interesting is the fact that some celebrities win more from commercials than from their actual jobs. If they enjoy a high level of awareness, credibility and charisma, that's enough. They associate their names with a brand and the money comes from itself for both the company and the star. The celebrity endorsement is helpful for the companies, as they differentiate themselves by the celebrity advertisements of the competition and in addition, the turnover increases very quickly, if the products are promoted by a star (Greenman, 2014). In addition, the celebrities help to strengthen a brand. For example, Louis Vuitton has used Keith Richards, the legendary performer of Rolling Stones, in all commercials. He appeared mostly in outdoor advertising and has strengthened the luxury image of the brand (Kotler \& Kelly, 2011). Over the years, many other models and VIPs such as Jennifer Lopez, Madonna or Audrey Hepburn promoted this brand. So, this company has used ambassadors in its marketing efforts for High Fashion Celebrity Brand (Kotler \& Kelly, 2011).

The number of stars in the commercials has increased in recent years. The marketers have realized the influence of the Celebrity Brand Ambassadors in the buying decisions of the consumers. A star is able to replace missing properties of a product. They have a strong influence on the behavior of consumers and encourage them to buy certain products. People should identify themselves with the celebrities and ultimately with the products. Advertising with testimonials can be printed, electronic, on TV or through social media (Zipporah \& Mberia, 2014). Another aspect to consider is the Match Up. The endorser must fit with the promoted product, there must be a match up, only then the advertising is really efficient. The best case is when there is a relationship between the products and the profession of the celebrity. For example, the athletes should convince the audience about sports products (Till \& Busler, 2000).

A celebrity can also bring disadvantages for the image of a brand. If the testimonial has a negative image or an inappropriate behavior, this can be reflected in the advertised 
product. If the consumers will no longer like the celebrity, they will no longer like the promoted product. In addition, a celebrity can destroy a brand by promoting multiple brands. So they lose their credibility and the power of persuasion and the relationship consumer celebrity get slowly lost. An example would be David Beckham. The football player advertises a wide range of drinks, perfumes and shoes. This fact causes consumers to remember that they saw David Beckham, but they no longer remember the advertised product, they no longer catch the attention of the product, which is detrimental to the brand (Makumbura, 2015).

Another problem would be the overshadowing of the brand by the celebrity endorser. This is called the vampire effect (Erfgen et al., 2015). The celebrities are very familiar to the consumers, they activate a lot of associations in those memories. This cannot happen it the case of an unknown endorser. As a conclusion of many studies, when a product is promoted by a famous, attractive person, then the recall of the brand is lower. When the advertising contains an endorser which is also attractive but not famous, then the recall of the brand is higher. So, celebrities should endorse more familiar rather than less familiar brands, because only in this way they don't catch all the consumers attention and they don't have a negative impact on the advertising. In case of a higher brand familiarity is the negative effect of the famous endorser on the brand recall lesser. And otherwise in case of a lower brand familiarity is the negative effect of the celebrity endorser on the brand recall higher (Erfgen et al., 2015).

Companies spend every year over 50 billion dollars on celebrity endorsers (Zamudiu, 2015). Another important cost it's often overlooked: the companies risk to be rejected by the celebrity they want while negotiating. This rejection is critical, because the strategies of a company may all depend on a specific famous person, who should promote their products. That's the reason why companies are advised to offer also gifts to the celebrity endorsers. On the other hand, celebrities are advised to become more popular and to have more followers on the social media, so they can be attractive for the role of potential celebrity brand ambassador. So, the choice of a celebrity endorser is very important and difficult for a company. The celebrity endorsement can be associated to a brand alliance, where the celebrity is the human brand and the product which is the corporate brand. Both should match together and influence the purchase intention of the consumers and the brand differentiation on the market. Celebrities can transfer their personality on the corporate brand, especially in the beauty industry. For example Drew Barrymore signed with the cosmetics company CoverGirl thanks to her "energetic yet authentic spirit", while the actress took the commitment to "bring myself and my personality into it" (Zamudio, 2015).

\section{Methodology}

In order to determine the efficiency of celebrity endorsement and the most attractive elements for the attention of the consumer, an eye-tracking experiment has been carried out, analyzing four coffee advertisings. Two of the advertisings contained only product related elements such as the package containing the logo and a cup of coffee (advertising for product P1) and the logo and a cup of coffee (advertising for product P2). Two of the advertisings have shown a celebrity besides the product related elements. For product P3 the advertising has shown an international average known celebrity drinking a cup of coffee and the logo of the product. For product P4 the advertising has shown a national celebrity drinking a cup of coffee and the package of the product containing the logo. The respondents have watched the 
advertising printouts for 10 seconds. The eye-tracking experiment has been carried out on a sample of 25 persons.

\section{Results and discussion}

The results of the eye-tracking experiment showed that the participants definitely watch more the celebrity in the advertising than the logo or the product itself. In table 1, there can be observed that for the advertisings without a celebrity the average time the consumers have watched the product's logo is of $1157.9 \mathrm{~ms}=1.1579$ seconds ( $\mathrm{SD}=815.9$ ) which represents $76.7 \%$ of the total time watching the advertising. Moreover the hit ratio was $92 \%$, which means that 23 out of 25 respondents have watched the logo. In the case of the two advertisings containing celebrities, most of the time has been spent watching them. The average time watching the celebrities was of $1294.5 \mathrm{~ms}=1.2945$ seconds (SD $=850.1$ ), representing $78.7 \%$ of the total advertising watching time. The hit ratio was $100 \%$ for the international celebrity and $96 \%$ for the national star (24 out of 25 participants watched the advertising). For the advertising containing the celebrity, the average time spent on watching the logo of the product has dropped to $281.9 \mathrm{~ms}=0.2819$ seconds ( $\mathrm{SD}=377.6)$, representing only $17.2 \%$ of the total watching time. The hit ratio for the logo was only $52 \%$, meaning that only 13 of the respondents have watched the logo of the advertised product.

Table 1: Influence of the personality on the impulsive buying behaviour

\begin{tabular}{|c|c|c|c|c|c|c|c|}
\hline Product & $\begin{array}{c}\text { Item in } \\
\text { advertising }\end{array}$ & $\begin{array}{c}\text { Mean } \\
(\mathrm{ms})\end{array}$ & SD & $\begin{array}{c}\% \text { time spend } \\
\text { on item }\end{array}$ & Hit ratio & & \\
\hline \multirow[t]{2}{*}{$\mathrm{P} 1$} & P1 - Logo & 1505.2 & 831.0 & $78.0 \%$ & $100 \%$ & & \\
\hline & P1 - Product & 425.3 & 468.9 & $22.0 \%$ & $72 \%$ & & \\
\hline \multirow[t]{2}{*}{$\mathrm{P} 2$} & P2 - Logo & 810.6 & 646.1 & $74.4 \%$ & $84 \%$ & & \\
\hline & P2 - Product & 278.6 & 402.1 & $25.6 \%$ & $48 \%$ & & \\
\hline \multirow[t]{3}{*}{$\mathrm{P} 3$} & P3 - Logo & 148.0 & 273.8 & $10.6 \%$ & $32 \%$ & & \\
\hline & P3 - Product & 64.0 & 134.3 & $4.6 \%$ & $24 \%$ & & \\
\hline & P3 - Celebrity & 1179.9 & 896.3 & $84.8 \%$ & $100 \%$ & & \\
\hline \multirow[t]{4}{*}{$\mathrm{P} 4$} & P4 - Logo & 415.9 & 422.8 & $21.9 \%$ & $72 \%$ & & \\
\hline & P4 - Package & 73.3 & 803.0 & $3.9 \%$ & $16 \%$ & & \\
\hline & P4 - Celebrity & 1409.2 & 189.5 & $74.2 \%$ & $96 \%$ & & \\
\hline & & & & & & $\mathbf{F}$ & Wilks' $\lambda$ \\
\hline \multirow[t]{2}{*}{ P1 \& P2 } & Logo & 1157.9 & 815.9 & $76.7 \%$ & $92 \%$ & & \\
\hline & Product & 351.9 & 438.6 & $34.3 \%$ & $60 \%$ & & \\
\hline \multirow[t]{3}{*}{ P3 \& P4 } & Logo & 281.9 & 377.6 & $17.2 \%$ & $52 \%$ & $47.4^{*}$ & 0.674 \\
\hline & Product & 68.6 & 162.6 & $4.1 \%$ & $20 \%$ & $18.3^{*}$ & 0.842 \\
\hline & Celebrity & 1294.5 & 850.1 & $78.7 \%$ & $98 \%$ & $115.9^{*}$ & 0.458 \\
\hline
\end{tabular}

$\mathrm{N}=25$ participants in the experiment; $\mathrm{N}_{1}=25 * 4=100$ cases for the discriminant analysis, ${ }^{*} \mathrm{p}<0.001$,

The discriminant analysis results in SPSS show that the presence of a celebrity $(\mathrm{F}=115.9$, $\mathrm{p}=0.000, \mathrm{df} 1=1, \mathrm{df} 2=98, \lambda=0.458$ ) in an advertising changes the attention of the person watching that advertising. The focus of the consumer's attention is put on the celebrity, distracting the consumer from watching the logo $(F=47.4, p=0.000, \mathrm{df} 1=1, \mathrm{df} 2=98, \lambda=0.674)$ and from the product ( $F=18.3, p=0.000, d f 1=1, d f 2=98, \lambda=0.842)$.

As it can be observed in table 1 , the participants have watched the logo for a longer time in the advertisings without a celebrity. For the advertising of product P1 (without celebrity endorsement), the logo of the product has been watched $78 \%$ of the time $(1505.2 \mathrm{~ms})$ and 
has had a hit ratio of $100 \%$. The same situation has occurred for product P2, for which the logo has been watched $74.4 \%$ of the total viewing time $(810.6 \mathrm{~ms})$. In the case of the two advertisings endorsing celebrities the situation has been changed. For product P3, the celebrity has been the most watched element in the advertising with a percentage of $84.8 \%$ of the total time $(1179.9 \mathrm{~ms})$ and a hit ratio of $100 \%$. In opposition to this the logo has been watched for only $148.0 \mathrm{~ms}$ ( $10.6 \%$ of the total time), while the product has been watched for only $64.0 \mathrm{~ms}$ ( $4.6 \%$ of the total time). The hit ratio has been lower for both the logo $32 \%)$ and the product $(24 \%)$. A similar situation has occurred for product P4. The celebrity has been, with $74.2 \%$ of the time $(1409.2 \mathrm{~ms})$ and a hit ratio of $96 \%$, the most watched element in the advertising. The logo for product 4 has been watched for $21.9 \%$ of the time ( $415.9 \mathrm{~ms})$ and has had a hit ratio of $72 \%$. The package of the product has been watched for only $73.3 \mathrm{~ms}$ ( $3.9 \%$ of the time) and it has had a hit ratio of only $16 \%$.

\section{Conclusion}

The results of the research show that the presence of a celebrity in an advertising can distract the attention of the consumer from the logo or the product itself. Consumers tend to focus their attention on analyzing the celebrity and less the advertised product. The results reflect the fact that the view of the participants are focused on the international celebrity and on the internationally recognized Romanian actress. Only afterwards consumers will focus on the logo of the product, while the other elements are not that appealing.

The endorsement of celebrities in advertising has both positive and negative implications for the efficiency of the advertising. On one hand, the presence of the celebrity in the advertising has a positive impact on the consumer's recall of the advertising. On the other hand, the celebrity can distract the consumer from watching the brand and might lead to the fact that he/she remembers the advertising, but not necessarily the advertised product. For this reason, it is important to analyze carefully and develop wisely the advertising campaigns that endorse celebrities. Celebrity endorsement can be very efficient only if the placement of the logo, the product and the celebrity can make a differentiation for the advertised brand.

\section{References}

Albert, N; Ambroise, L; Valette-Florence P (2017), Consumer, brand, celebrity: Which congruency produces effective celebrity endorsements? Journal of Business Research, 81, 96-106.

Bagozzi, R. P.; Dholakia, U.M. (2002). Intentional social action in virtual communities, Journal of Interactive Marketing, 16(2), 2-21.

Bergkvist, L.; Zhou, K.Q. (2016). Celebrity endorsements: A literature review and research agenda. International Journal of Advertising, 35(4), 642-663.

Byrne, A.; Whitehead, M.; Breen, S. (2003). The naked truth of celebrity endorsement, British Food Journal, 105 (4/5), 288-296, https://doi.org/10.1108/00070700310477086

Devue, C; Van der Stigchel, S; Brédart, S.; Theeuwes, J (2009). You do not find your own face faster; you just look at it longer, Cognition, 111, 114-122.

Erfgen, C, Zenker, S, Sattler H. (2015). The vampire effect: When do celebrity endorsers harm brand recall? International Journal of Research in Marketing, 32, 155-163.

Friedman, H. H., \& Friedman, L. (1979). Endorser effectiveness by product type. Journal of Advertising Research, 19(5), 63-71. 
Greenman, A. (2014). 10 Of The Most Successful Celeb Endorsements Of All Time, The Richest 2014. Retrieved from: http://www.therichest.com/rich-list/most-influential/10-ofthe-most-successful-celeb-endorsements-of-all-time/ (accessed on: 03.05.2017)

Holmes, S.; Redmond, S. (2014). Socialising celebrity. Celebrity Studies, 5(3), 223-224.

Kotler P.; Keller, K.L. (2008). Managementul Marketingului, Teora (5 ${ }^{\text {th }}$ Ed.).

Kotler, P.; Armstrong, G. (2011). Principles of Marketing (14th Ed), Pearson Prentice Hall.

Kotler, P.; Keller, K.L. (2011). Marketing Management (14th Ed). Pearson Prentice Hall.

Makumbura, U. (2015). The Power Of The Celebrity Endorsements Today, London School Of Marketing, Retrieved from: https://cdn2.hubspot.net/hubfs/211508/ The_Power_of_Celebrity_Endorsements.pdf?t=1461152996975 , (accessed on: 3.01.2019)

McCracken, G., (1989). Who is celebrity endorser? Cultural foundations of the celebrity endorsment process, Journal of Consumer Research, 16(3), 310-321

Mehta, A. (1994). How advertising response modeling (ARM) can increase ad effectiveness. Journal of Advertising Research, 62-74 May/June.

Nistoreanu, P.; Dinca, V.M.; Schiopu, A.F. (2017), Competition Policy in the European Film Industry Focused on Consumers' interests-A Romanian Perspective, Amfiteatru Economic, 19 (45), 253-269.

Pop, N.A., Baba, C.A. (2018), Factors influencing adventure tourism in Romania in a sustainable perspective, 4th BASIQ International Conference on New Trends in Sustainable Business and Consumption (BASIQ), pg. 226-233.

Pop, N.Al. (2018), Quo Vadis Romanian Marketing: The Future and Contribution of the Romanian Community, in: Vaduva S.; Wilt, R.; Fotea, I.; Vaduva L.P. (2018): Civil Society: The Engine for Economic and Social Well-Being, Springer.

Popa, A.; Pelau, C. (2016), Differences in the clothing brand perception depending on generation, Industria Textila, 4, 260-264.

Schau, H. J.; Muñiz, A. M.; Arnould, E.J. (2009). How brand community practices create value. Journal of Marketing, 73(5), 30-51.

Stöwing 0. (2016). Promi - Werbung, Berliner Morgenpost. Retrieved from: http://www.morgenpost.de/vermischtes/article208025527/Promi-WerbungManchen-Stars-kauft-man-einfach-alles-ab.html (accessed on: 01.05.2017).

Till, B.; Busler M. (2000). The Match-Up Hypothesis: Physical attractiveness, expertise and the role of fit on brand attitude, purchase intent and brand beliefs, Journal of Advertising, 29(3), 1-13.

Zamudio, C. (2016). Matching with the stars: How brand personality determine celebrity endorsement contract formation, International Journal of Research in Marketing 33 (2016) 409-427.

Zipporah, M.M.; Mberia, H. (2014), The Effects OF Celebrity Endorsement in Advertisements, International Journal of Academic Research in Economics and Management Sciences, 3(5) 2014. Retrieved from: http://hrmars.com/hrmars_papers/ The_Effects_OF_Celebrity_Endorsement_in_Advertisements.pdf (accessed on: 3.01.2019). 